\title{
The Ivanovo State Power Engineering University Turns Eighty
}

\author{
DOI: $10.1134 / \mathrm{S} 004060151008001 \mathrm{X}$
}

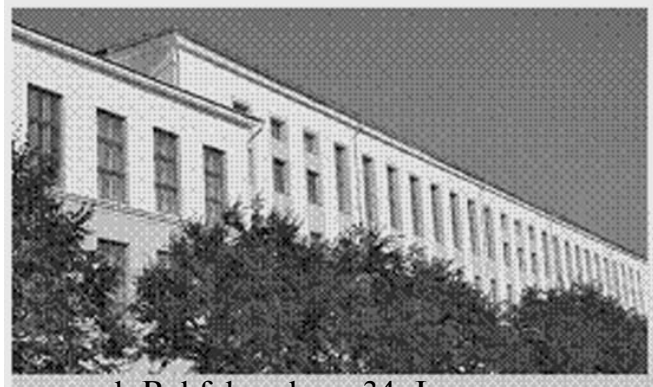

ul. Rabfakovskaya 34, Ivanovo
ИВАНОВСННЙ ГОСУДАРСТВЕННЫЙ ЭНЕРГЕТИЧЕСННЙ УНИВЕРСНТЕТ

The Ivanovo State Power Engineering University (IGEU) was established on July 23, 1930 by the Decree of the Central Executive Committee of the Soviet Union's Council of People's Commissars No. 40/237 on the basis of the Engineering-Mechanical Department of the Ivanovo-Voznesensk Polytechnic Institute, which was established on August 10, 1918 by the Decree of the Russian Soviet Federative Union Republic's Council of People's Commissars.

For the advances in training engineers for the power industry and its scientific work, the institute was named after V.I. Lenin by the Decree of the Soviet Union's Supreme Soviet dated November 28, 1938. In 1980 , IGEU was awarded with the "Sign of Honor" Order by the Decree of the Soviet Union's Supreme Soviet dated June 23, 1980.

More than 50000 specialists for the power industry, industries constructing machinery and instruments, for the defense complex of Russia, and other industries have been educated at IGEU over the time of its existence. In 1999, a machinery construction complex was included in the university, and a branch of IGEU was opened in the Raduzhnyi town of the Khanty-Mansi Autonomous Area.

At present, more than 8000 students and 200 postgraduate students are educated at IGEU. The university conducts training in 98 education programs, including 48 disciplines and 50 additional qualification courses. These programs cover electric and thermal power engineering, nuclear power stations, electromechanics and machinery construction, microelectronics, space communications, information technologies, economics, sociology, and PR-specialties. The university conducts education of post-graduate students in 27 programs; scientific councils considering doctoral dissertations on eight disciplines work at IGEU. High-skilled instructors are engaged in conducting education; $73 \%$ of them have scientific degrees and titles.

IGEU is a large education-scientific and production complex. It has five education-laboratory buildings, a multidisciplinary fleet of equipment, a modern gas-fired boiler house, dormitories and canteens, and its own TV studio. The scientific-technical library of IGEU contains more than 2 million copies. The overall area of IGEU, which is organized as a campus, totals $126000 \mathrm{~m}^{2}$.

The thermal power engineering department (TPED) is one of its basic departments and has deep historical traditions. The professors of the Riga Polytechnic Institute V.V. Sushkov and A.A. Borneman, well-known specialists in thermal engineering, were the founders of the department. M.S. Maslennikov, B.I. Shaposhnikov, V.F. Vikhrev, P.I. Khranilov, P.A. Baklushin, P.V. Troshin, and G.K. Filonenko, who were the disciples of Suchkov and Borneman, as well as professors B.M. Yakub from the Moscow Power Engineering Institute and G.I. Petelin from the Leningrad Polytechnic Institute, developed the thermal power engineering line and organized the TPED. Subsequently, professors V.S. Kaekin, S.G. Ushakov, M.I. Shchepetil'nikov, A.T. Lebedev, and A.V. Antipin made great contributions in the further development of the department.

The number of IGEU graduates demanded by employers outgrows the supply by a factor of $2-3$ on the average; for many specialties, this disproportion is even still higher. The list of organizations that are the largest employers of graduates from IGEU includes the power industry enterprises of united and territorial power-generating companies (primarily those of Yaroslavl, Belgorod, Nizhni Novgorod, Vladimir, etc.), the 
Rosenergoatom Concern, large power stations (such as the Kostroma district power station and Kalinin nuclear power station), petroleum refining and chemical industries, metallurgical, machinery construction enterprises, design offices, and erection organizations.

At present, IGEU is a rapidly developing higher school at which advanced informational technologies of education are developed and used, including fullscale and local training simulators.

On behalf of the university administration and personally from myself, I congratulate the instructors, workers, students, and graduates on the 80-year anniversary of the university and wish them sound health, personal happiness, and further creative success in their hard work for the benefit of native IGEU and the entire power industry.

S.V. Tararykin,

Rector of IGEU, Doctor of Technical Sciences, Professor, Honored Science Worker of the Russian Federation

I am sure that the Russian electric power industry will make the necessary swing in its development. The future of the Russian power industry is with united companies established on the basis of united power systems.

I wish power engineers, former and future graduates of the Ivanovo Power Engineering University to work as a single team at their companies and to be confident that we will win working together.

V.V. Kudryavyi, Doctor of Technical Sciences, Professor, Vice President of RAO Unified Energy Systems of Russia, Deputy Minister of the Russian Federation for Fuel and Power in the 1990s, graduated from IGEU in 1961.

IGEU graduates were forwarded not only to the central power systems of Russia, but also to Far East and Siberian regions. IGEU graduates have always been distinguished by being devoted to their chosen specialty, high level of skills, and diligence. Many of IGEU graduates succeeded in making considerable achievements in their work and received state awards of Russia. As it regards IGEU instructors, I maintain close and good relations with them still at present. Many of them are my college mates.

\section{A.Ya. Kopsov, \\ General Director of Enel OGK-5, Doctor of Technical Sciences, Vice President of RAO Unified Energy Systems of Russia in the 1990s, General Director of OAO Mosenergo in 2005-2008, Chairman of the IGEU's Board of Guardians, graduated from IGEU in 1965.}

The Editorial Board of the Teploenergetika journal heartily congratulates the staff and graduates of IGEU on the 80th anniversary of the university and wishes them further creative success for the benefit of Russian power engineering. 